\title{
The Application of Performance Measurement Systems at the Electricity Sector of Lithuania
}

\section{Linas Jasiukevicius, Ceslovas Christauskas}

\author{
Kaunas University of Technology \\ K. Donelaicio st. 20, LT-44239, Kaunas, Lithuania \\ e-mail: linas.jasiukevicius@gmail.com,ceslovas.christauskas@ktu.lt
}

crossref http://dx.doi.org/10.5755/j01.ee.22.3.518

This article presents the results of the empirical research performed in Lithuanian grand electricity companies in order to reveal the application of performance measurement systems (PMSs) at the electricity sector.

The relevance of the performance measurement at the electricity sector is determined by starting the process of gradual electricity market liberalization which changes performance conditions of companies operating in this sector. Scientific literature within the context of the analysis of such processes impact on the performance measurement and PMS in this sector is poor and fragmentary. This paper is the first one in which it is analyzed the performance measurement in Lithuanian electricity companies.

Theoretical background of the research is based on the assumptions that the changing environment of an organizational the performance has a direct impact on the changes of performance measurement which, in its turn, are realized in close connection with the projects on reorganizing PMS (Ponikvar, Tajnikar and Pushnik, 2009; Gimzauskiene and Valanciene, 2009; Gimzauskiene and Kloviene, 2010). According to this approach, the appropriate changes in electricity market allow to presume by increasing the importance of the evaluation of nonfinancial indicators, herewith and the relevance of the application of modern PMSs.

Following these presumptions, the features of the performance measurement and changes of PMS due to electricity market liberalization were analyzed. The research was performed in free types of electricity companies in order to explore the specification of performance measurement and the impact of market liberalization on it in different types of companies. In total four Lithuanian grand electricity companies were researched which were selected by handily selection method.

The main results disclosed that due to short time electricity market liberalization still has not had considerable impact on the performance measurement of companies. Traditional attitude to performance measurement mostly based on financial indicators and traditional functions of performance measurement was dominant. However, the research revealed that the importance of nonfinancial indicators was growing. These changes were mostly related with the increasing relevance of the measurement of strategy implementation, customers and other stakeholder satisfaction and workers evaluation. Together with the indicators of these ranges it was envisaged the increasing relevance of the application of modern PMSs, especially in the company of electricity generation. The research disclosed that the increasing competition between independent suppliers gradually increased the importance of a competitive strategy formation and the measurement of non-financial indicators. Therefore, in this company the application of modern PMS as the means of strategy implementation was foreseen more relevant in comparison with other types of electricity companies.

Keywords: electricity sector, electricity market liberalization, features of performance measurement, performance measurement system, strategic management.

\section{Introduction}

In order to get competitive advantages, organizations must be able to foresee the changes of external environment and respond to them more quickly than competitors. Therefore, organizations have constantly to monitor and analyze their performance and to evaluate the results of strategic goals implementation (Christauskas \& Stunguriene, 2007). According to Rantanen, et al., (2007); Curado \& Manica (2010) the setting of the strategic goals of an organization and the measurement of their implementation has become a widespread strategic management tool and the demand to evaluate the results of implementing strategy is growing. However, at the same time the findings of many studies demonstrate that the traditional performance indicators based on the accounting data are still dominant in the evaluation of the most organizations' performance (Roa, 2006; Bogicevic \& Domanovic, 2009). Therefore, managers by forming PMS often face with a problem how to reliably measure the performance of the organization and success in the implementation of the intended strategy (Wouters \& Sportel, 2005).

One of the main problems of PMS application in the organization determines the absence of one of the best PMS and the best method of the choice of PMS. Most recent management accounting researches are based on contingency theory (Gimzauskiene \& Kloviene, 2008, Slizyte, 2009; Gimzauskiene \& Valanciene, 2009; Valanciene \& Gimzauskiene, 2009). According to this approach, the choice of PMS is understood as an individual formation of the system for every organization. Therefore, PMSs even of the same name can highly differ by their indicators in every organization. 
On the other hand, over the last two decades the changes in the world market formed the requirements of modern PMS. It was realized that traditional performance measures mainly based on the accounting data are insufficient to measure all value creating factors in the contemporary rapidly changing and highly competitive market. Despite the fact that the traditional measures are defined, accurate and easily comparable authors criticize them for lacking strategic focus; encouraging shorttermism; encouraging minimization of variance rather than continuous improvement; encouraging local optimization; being internally rather than externally focused, with little regard for competitors or consumers and often inhibit innovation (Parker, 2000; McAdam \& Bailie, 2002; Kennerly and Neely, 2003; Anderson \& McAdam, 2004; Dagiliene, et al., 2006; Unahabhokha, Platts \& Tan, 2007; Galiniene \& Marcinskas, 2007; Kazlauskiene \& Christauskas, 2008; Slizyte, 2009; Christauskas \& Kazlauskiene, 2009). Therefore, considering this limitation during this period, there were presented and spread various advanced PMSs such as Balanced Scorecard (BSC) (Kaplan \& Norton, 1992), Performance Prism (PMP) (Neely, et al., 2001), Performance Pyramid (SMART), (Lynch \& Cross, 1991), European Foundation and Quality Management (EFQM) Excellent Model and other. These systems by different level include a wide range of both financial and non-financial groups of measures such as strategy implementation, consumers and others stakeholders satisfaction, internal and external business processes, workers, competitive abilities and goals, capacity of organization and recourses, quality, innovation, perfection, learning, leadership, and others that allow to getting a comprehensive view of organization's performance.

However, the studies of Parker (2000); Grodskis, Staskevicius \& Zemkauskas (2001); Kennerley \& Neely (2003); McAdam \& Bailie (2002); Tapinos, Dyson \& Meadows (2005); Neely, Gregory \& Platts (2005); Wouters \& Sportel (2005); Kaplan \& Norton (1992); Tangen (2005); Haapasalo, Ingalsuo \& Lenkkeri (2006); Rantanen, et al., (2007); Pongatichat \& Hohnson (2008); Walsh \& Sanderson (2008); Lenz, B. (2008); Neely (2005); Gimzauskiene \& Valanciene (2009); Slizyte (2009); Valanciene and Gimzauskiene (2007); Strumickas and Valanciene (2009); Turskis, Zavadskas \& Peldschus (2009), Jasilioniene \& Tamosiuniene (2009); Kloviene \& Gimzauskiene (2009); Kinderyte, Ciegis \& Staniskis (2010), primarily modern PMS closely relate with competitive strategy of organizations as a management tool for the regulation of strategic management functions. Nowadays market tendencies determine that the setting and implementation of strategic goals and the evaluation of their implementation results became a prevalent way of organization management. Therefore, the coherence of strategy and performance measurement is the essential feature of modern PMSs. Modern systems are also characterized as having balance between financial and nonfinancial indicators, emphasizing binding of strategic goals and day-to-day operations, reflection of cause-effect relations, orientation to the processes and appropriateness to apply them by tactical and operational levels. These changes of PMSs over two decades demonstrate that the changing environment of organizational performance has a direct impact on performance measurement and also usable PMS (Ponikvar, et al., 2009; Gimzauskiene \& Valanciene, 2009; Gimzauskiene \& Kloviene, 2010).

Although modern PMSs are characterized by the same elements and features of performance measurement they vary from each other. Each of them has its own advantages and disadvantages. Therefore, one of the main challenges is to choose a set of indicators that would clearly reflect organization's performance and effectiveness of its strategy implementation.

Recently, Lithuania is undergoing profound changes in the electricity sector. In 2010 there started a gradual process of electricity market liberalization and similar examples from other countries allow to presume the increase of competition and diversification (Haapasalo, et al. 2006; Muller, Steinert \& Teufel; 2008; Ginevicius, 2009; Ginevicius \& Podvezko, 2009). Therefore, the development of an individual strategy and the measurement of its results implementation have gained more important role. However, such changes of performance conditions for the companies for a long time operating in regulated electricity sector can be a considerable challenge to increase their efficiency of performance through the strategic positioning. Due to these changes it is important to find appropriate means which would allow to measure organization's performance and its strategic goals implementation effectively. Therefore, the research problem is formed as a question: why and how are PMS applied in Lithuanian grand electricity companies?

The purpose of this article is to explore the application of PMSs and their changes in Lithuanian grand companies of electricity generation, transmission and distribution by implementing the following steps: 1) Analyze the peculiarities of PMS in the electricity companies. 2) Explore the impact of market liberalization on the performance measurement of electricity companies.

Relevance and novelty of the article. A lot of articles in Scientific literature analyze various problems of the usage of PMSs. However, there is little research what PMSs are used or would be applied in electricity companies. Haapasalo, et al., (2006) analyzed the peculiarities of application of BSC in Finish energy sector (including electricity sector). The Case study of Bromley, et al., (2006) described the application of BSC in "EDF Energy" company of electricity generation, transmission and distribution in the United Kingdom. These articles analyzing the usage of one system disclose only fragmentary the view of the application of PMSs in such type of companies. This demonstrates that the performance measurement and the application of PMSs in these companies are analyzed insufficiently. This article is the first study wherein there is researched the performance measurement and the application of PMSs at the electricity companies of Lithuania.

The object of the research is PMSs and the indicators of the performance in Lithuanian grand companies of electric power generation, transmission and distribution. 


\section{Research methodology}

In Lithuania there are about 30 companies operating in the electricity energy business. Most of these are medium or small companies having license of independent supplier and also operating in other business activities such as producing and selling heating energy, logistics, manufacturing and others. Only the largest companies are entirely operating in electricity sector. Therefore, in order to explore the application of PMSs and their changes in Lithuanian electricity organizations the grand companies of electricity generation, transmission and distribution were researched.

The research was performed in May - June 2010. We interviewed all four Lithuanian grand electricity organizations which were chosen by handily selection method by their size, long lifetime and considerable significance in the electricity sector of the country. Considering these criterions, the biggest electricity plant of Lithuania which can meet the requirements of the country, organization of electricity transmission which works by natural monopolistic conditions and two the biggest organizations of electricity distribution which eqralty cover almost all the territory of the country were included in the research. In total, five top managers directly related with the measurement of company performance as experts were interviewed: two of them in the company of energy transmission and three managers in other companies.

Interviews were performed in the companies' offices. All managers were provided by the list of questions beforehand in order to allow them to prepare for the interviews. This allowed getting comprehensive data.

The research consisted of two main parts. 1) The features of performance measurement 2) The impact of implementing free electricity market to performance measurement and PMS. The aim of the first part was to analyze the features of the performance measurement and the usage of PMSs. It consisted of four groups of questions. In accordance with Haapasalo's, et al. (2006) who named the theoretical purposes of the usage of PMS, it was sought to analyze the aspects of the usage of performance measurement in the first group. In the second group it was sought to find out what PMSs and how long they are used in the electricity organizations. In accordance with Slizyte's (2009) who characterized the theoretical features of PMS, it was sought to analyze which of them are specific in the PMS of electricity organizations in the third group. Finally, in accordance with CEEPP that formed the indicators of the integrity of PMSs, the issues were analyzed in the last part. These analyses were made keeping is the approach that, if companies use several PMSs, they are used integrally. Therefore, they can be analyzed as one integrated PMS.

The second part of the research was intended to explore the impact of free electricity market on the performance of electricity companies and their performance measurement. It includes two groups of questions. In the first group there were questions concerning the impact of electricity market liberalization on the performance and PMSs of electricity organizations. In accordance with Slizyte's named features of modern PMS, it was sought to analyze their importance in the measurement of organization performance in the second group. In order to evaluate the impact of free market on the importance of these measures, their importance was assessed in three different periods (3 years ago, at present and after 3 years.). The importance was understood as relevance to use and frequency of usage in performance measurement. Overall 23 groups of measures were assessed.

In order to gather more précised data and to have their possibility of comparison, most questions were made in the way that the respondents had to answer them using Likert scale also by clarifying answers extensively. Data was analyzed using the method of Content analysis.

\section{Results and interpretation}

The features of the usage of performance measurement. The research disclosed that the control of organization performance was the main goal of performance measurement in all electricity companies. All managers stated that generally performance measurement was used for monitoring the results of operational performance and ascertaining the deviance of performance from intended goals or standards. More or less performance measurement was used for the evaluation of strategic goals implementation and their formation. Moreover, considerable distinctions regarding these points in every type of organizations were observed. Comparing with other groups most performance measurement was related with the evaluation of strategic goals implementation in the companies of electricity distribution. Managers of these companies revealed that they had several measures which helped to evaluate whether companies perform effectively in the implementation of strategic goals mostly focused on consumers' satisfaction. Meanwhile the strategic goals of the company of electricity transmission regarding its specifics of performance were mostly related with internal environment. Therefore, the measurement of the implementation of strategic goals in this company was less relevant in comparison with the companies of distribution. In the company of electricity generation the evaluation of strategic goals implementation was only partly performed. Managers stated that the main goal of this company was to be always ready to meet the demand of electricity in any circumstances. Therefore, such mission of the company determined that more attention was given to the measurement of the performance flexibility rather than the implementation of strategic goals.

Even less performance measurement was used for the formation of the strategy. This feature of performance measurement was asserted only in the companies of electricity distribution. However, these possibilities were very restricted because of the regulation of government. Grand electricity companies are strategic objects therefore they cannot choose their own strategy independently. Managers stated that the formulation of strategy more depended on political or geo-political decisions than top-managers' decisions. As a result, in the companies of electricity distribution the formation of strategy is confined by internal environment and customers' satisfaction. Meanwhile in the companies of transmission and generation strategy's formation by their own had been not performed. 
Used PMS. The research disclosed that the Activitybased system $(\mathrm{ABC})$ was the most often used PMS by electricity companies (Table). This determined the requirement to accurately estimate all costs. Managers named the reduction of operational costs and increase of efficiency as the main factors of success in energy business and accurate cost accounting system enabled companies to achieve these goals.

All companies also used some form of assessment of employees' performance. However, each company used different performance measurement systems of employees (EPMS). In the company of electricity generation the evaluation of workers was included in the BSC as a part of perspective of internal process. Meanwhile other companies used separate EPMSs. Particularly attention for them was paid in the companies of electricity distribution although their attitude towards evaluation of workers' performance was very different. One was more focused to the achievement of strategic goals: did not allow workers to go with the stream and forced them to orient not to the process but to the results, providing two-way communication between workers and managers in all levels of strategy's implementation. Meanwhile another company was confined by evaluation of workers only in the operational level. These differences of similar companies could be explained only by different attitudes of managers to the management of organizations. In the company of electricity transmission EPMS also was closely related with the implementation of organization's strategic goals. However, this system was just started to implement therefore it was not analyzed in more detail.

Table 1

Used PMSs in Lithuanian grand electricity companies

\begin{tabular}{|l|l|l|}
\hline \multicolumn{2}{|l|}{$\begin{array}{l}\text { Type of electricity } \\
\text { companies }\end{array}$} & \multicolumn{1}{c|}{ Used PMSs } \\
\hline Generation & BSC; ABC. \\
\hline \multicolumn{2}{|l|}{ Transmission } & ABC; EPMS; QMS. \\
\hline \multirow{2}{*}{ Distribution } & $\mathbf{C 1}$ & $\begin{array}{l}\text { ABC; BSC (suspended, used only some } \\
\text { elements), EPMS. }\end{array}$ \\
\cline { 2 - 3 } & $\mathbf{C 2}$ & ABC; EPMS. \\
\hline
\end{tabular}

Half of the researched organizations used BSC (co. of generation and one co. of distribution). However, regarding the earlier preposition that company of electricity generation paid little attention to the strategy the use of this system was indeterminate in this company. Moreover, the manager could not explain more about the use of BSC. Therefore, further analysis of this company's peculiarities of performance measurement was performed considering that there were used only several elements of BSC in this company. These assumptions were strengthened by the fact that other company of distribution also used only separate parts of this system. The manager stated that fully-implemented BSC has more than 200 measures in this company. As a result it took too much time and costs to calculate everything. These findings partly confirmed the results of research done by Haapasalo, et a., (2006), Neely and Bourne (2002) that the most attempts to fully implement BSC fail. Quality management system (QMS) is used only in the company of electricity transmission.
Features of PMS. The research revealed that financial measures were dominant in the PMSs. Nonfinancial measures only supplemented them in order to get comprehensive view of organization's performance. Therefore, the statistical balance of financial and nonfinancial measures which is considered as a peculiarity of modern PSM have been not observed in any of organizations. On the other hand, managers considered the level of balance not by equal numbers of both types of measures but whether their proportion satisfies the requirements of the company. Following this approach managers were satisfied with the used PMSs.

The research also disclosed that PMSs of all companies are generally characterized as encouraging permanent perfection and giving feedback as an instrument of performance management. Other features of systems are asserted differently.

It was revealed that PMSs more or less emphasized the implementation of strategy in all companies. This disclosed that all companies also used PMSs level for the achievement of their strategic goals ata different. Managers considered their PMSs as suitable for the use in the strategic and tactical levels. However, the appropriateness to use them in operational levels varied. It was observed that PMSs which were more aligned with strategy were less appropriate to monitor and evaluate the performance of daily operations. According to the managers, it was frequently difficult to evaluate how day-to-day actions were contributing to the implementation of strategy. The managers of more strategy-focused companies (one co. of distribution and co. of transmission) reported that the measurement of performance in the operational level is performed only 2 or 3 times a year while other companies (another co. of distribution and co. of generation) which are less focused on strategy evaluate their performance more often. The last-mentioned companies also characterize as almost not linking the measurement of strategic goals with day-to-day operations.

As one of the most important features of modern PMS, there was analyzed their simplicity of perception and use. The interviews disclosed that the systems were easily perceived by all workers only in the companies where PMSs have not changed for a relatively long time, at least for two years. The systems of other companies have been constantly changed or improved over the past year, therefore they were constantly in a testing stage, unstable and at the same time difficult enough to be understand by those whom they concerned. However, it was observed that at the same time these systems were more complex, included wider range of measurement areas and more related with the strategy than the first one.

Integration of PMSs. As one of the most important features of modern PMS integration of systems were searched, it was disclosed that the integrity of performance measurement through the management levels of organization was different in the companies. The differences mostly related with the evaluation of workers. The systems of half of the companies (co. of generation and one co. of distribution) included the evaluation of workers in all hierarchical levels. While in the systems of other companies (co. of transmission and another co. of distribution) the evaluation was performed only in the 
highest and middle levels, the research revealed that the evaluation of workers was more advanced in the latter companies. As a simple evaluation of the work results has shower, two times a year top and middle level managers had individual conversations in which there were assessed not only work results, but also discussed organization's goals and heard individual expectations in order to be sure that all employees would work in one direction in order to achieve companies' strategic goals. The workers of the lowest level of these companies as well as all employees of the first two companies were assessed only by the results of work. However, the number of employees assessed by more advanced systems was constantly growing. That disclosed that the demand of assessment of workers was constantly growing too.

The research also revealed that PMSs of all companies enabled to include all areas of organization's performance. However, the role of PMS was small enough in the integration of separate elements of companies. Managers reported that systems themselves were weak in the evaluation of how performance of one department influenced the performance of other department. As a result, in all systems internal communication between separate departments was also little encouraged. Therefore the coordination of separate departments mostly was put on the management of the top managers.

Most companies' PMSs were standardized and documented. Managers reported that companies had explicit methodology of what and how had to be measured and evaluated e.g. it was clearly determined that the list of measures should be measured and the forms of evaluation with a prepared scale of measurement: a form for workers and a form for managers. Only one company (one of distribution co.) distinguished itself as having no strict descriptions and standardized scale of performance measurement. This difference could be explained by the changes of PMS which were constantly done in order to improve the evaluation of employees.

Natural monopolistic conditions of performance of almost all companies determined that there was paid little attention to the evaluation of external environment. Only the company of electricity generation regarding the specific of performance analyzed the changes of fuel markets in order to evaluate fuel alternatives and optimize the costs. Therefore, unlike as it is in highly competitive sectors, PMSs of all electricity companies had not or almost had not included the evaluation of proactive measures, relations with customers and suppliers, customer satisfaction.

The impact of free electricity market on the performance of organizations and their PMSs. One of the main reasons of electricity market liberalization is the objective to increase competition as wellas to decrease the final price of electricity for consumers. However, it was disclosed that certain changes of pricing policy were realistically foreseen only in the company of electricity generation. Since 2015 when the public regulation of prices will be fully abolished this power-station as an independent supplier of electricity will be able to perform pricing itself. At the same time the pricing policy of this company will become more intensive. However, a manager reported that the process has just started and it takes time to evaluate these changes. Regarding the liberalization of electricity market, other companies did not experience any changes of pricing policy and did not expert suppose them in the future.

The research disclosed that the market liberalization has not influenced the intercourse with consumers in 3 of 4 companies yet (Both co. of distribution and co. of transmission). However, in one of the two companies of electricity distribution it was undergoing significant changes in the relations with consumers. Instead of focusing only on safe and reliable distribution of electricity, it was also started to pay great attention on the service of consumers and their satisfaction as well. Regarding these changes, a new strategy was adopted. However, taking into account that companies of electricity distribution will lose a license of public distribution and not be able to sell electricity, these changes of strategy could be more related with not market liberalization but with the objective of the very company to improve the service of consumers. This argument was also supported by the proposition of the manager of other company of electricity distribution that regarding market liberalization there were no any significant reasons which could encourage changes in the strategy. As a contrast in this company, there have been no changes or innovations regarding the strategy in the latter company of electricity distribution. Therefore it can be stated these differences of companies of distribution were more related with individual management decisions of top managers than with a starting process of liberalization.

Only in the company of electricity generation there were foreseen considerable changes regarding electricity market changes. The manager reported that since 2015 starting to sell electricity to all consumers it will be important to create the infrastructure of consumer service, train the staff and invest more to marketing. In order to prepare for these changes it will be important to form new competitive strategy. Therefore, the company of electricity generation could be considered as the one being the most influenced by liberalization of all electricity companies in the future.

Regarding these changes of performance of electricity companies, it can be stated that there have been made no significant changes in PMSs concerned with starting market liberalization. However, for previously aforesaid reasons, changes are foreseen mostly in the company of electricity generation in future. The Manager reported that every year of consumers could freely choose the electricity supplier and more attention will be paid to the attraction of consumers, increase of attractiveness and enhancement of competitiveness. Accordingly, the development and implementation of competitive strategy will be more relevant. As a result, in this direction PMS world change in order to effectively measure the performance of this company by new conditions of performance. It could be supposed that the use of PMS as a tool for competitive strategy implementation would have to be the most relevant in the company of electricity generation in comparison with other types of electricity companies. 
Linas Jasiukevicius, Ceslovas Christauskas. The Application of Performance Measurement Systems...

The importance of performance indicators. All managers unanimously named the financial indicators as the most important aspects in the evaluation of companies' performance in all periods. As very important groups of indicators there were also mentioned indirect costs, learning, perfection, quality and innovations. Moreover, the analysis disclosed that the importance of these nonfinancial indicators especially of the last two groups will increase in 3 - 5 years,. Constantly tightening environmental requirements force to improve available and new technologies reducing environmental pollution and increasing the efficiency of performance. The indicators of intellectual capital were also mentioned as very important group of indicators. The analysis disclosed that the indicators of both people and organization as well as communication capital were named as very important in the evaluation of performance of all companies. Moreover, considering the changes of electricity market, their importance would have to increase too.

The importance of other groups of indicators and features of changes of their importance differed between the companies of electricity generation, transmission and generation. In the company of electricity generation as very important groups of indicators in all periods there were named an internal process, competitive abilities, capacity of organization and recourses, flexibility and public results. Concerning electricity market liberalization foreseen the increase of importance of indicators of customer and other stakeholder satisfaction, strategy implementation, workers, external process and leadership is foreseen. The two latter groups of indicators have not been evaluated yet. However, they were foreseen as being part of all integrated PMS in the future. Other groups of indicators such as indicators of productivity and stakeholder contribution were not measured and their evaluation was not foreseen in the future too.

The research revealed that regarding market liberalization, significant changes of importance in most indicators have hat been foreseen yet. Groups of indicators of workers, other stakeholder satisfaction and productivity were named as very important indicators in the company of electricity transmission in all periods. Averagely important groups of indicators of evaluation were flexibility, public results, capacity of organization and recourses, stakeholder contribution, customer satisfaction and external process. The managers also named the groups of indicators of internal process and leadership as averagely important. However, in order to improve efficiency of performance their importance would have to increase in the future.

In the companies of electricity distribution the groups of indicators of competitive ability, capacity of organization and recourses were named as being little important. The research revealed that regarding the features of performance of these two companies, the increase of importance of indicators of competitive ability was not foreseen. However, the measurement of the capacity of organization and recourses closely related with human resource management to. Other groups of indicators named in the measurement of the previous companies were considered as very important. Moreover, according the managers, their importance would increase.

\section{Conclusions}

1. According to theoretical assumptions, company success depends on the effective measurement of company's performance. The more relevant are the company's performance indicators in PMS, the better ability is to properly react to changes and manage performance effectively. Therefore, the company must have appropriate indicators from an operative environment and form PMS which would allow to getting comprehensive information about the company's performance.

2. Concerning the results of scientific literature, it can be stated that performance measurement and requirements for PMSs constantly change together with changing companies' performance environment and values. Contemporary competition conditions highlight the importance of strategy and other non-financial indicators. Interface between company's strategy and performance measurement, also the balance between financial and non-financial indicators are considered as essential features of modern PMS.

3. In Lithuania there started the process of electricity market liberalization and it gradually changes the conditions of performance of electricity companies: increases competition and relevance of customer requirements satisfaction. These changing conditions allow to presume that the application of modern PMS becomes more relevant.

4. According to the results of the empirical research in Lithuanian, it can be stated:

- In electricity companies performance measurement is mostly applied as an information function to manage and control the performance of companies. Political regulation determines that companies' role of performance measurement is relatively little by forming and implementing individual strategy and mainly confines by internal environment.

- $\quad \mathrm{ABC}$ was the most used PMS among companies; all companies performed evaluation of employees. During recent years the most significant changes were made in the evaluation of employees' performance: the number of evaluated workers increased, more advanced employees' evaluation systems were applied.

- Although PMSs of all companies were characterized as emphasizing strategy implementation and by the appropriateness to use them in strategic management financial evaluation was dominant in all companies' performance measurement.

- The aspect of integrity of PMSs of all companies was very similar: it included wide spectrum of performance areas, was focused more on the internal environment rather than the external environment, most of PMSs were standardized and documented.

5. According to the results of the empirical research of the impact of electricity market liberalization on the performance measurement and indicators of PMSs of Lithuanian grand electricity companies, it can be stated:

- Concerning electricity market liberalization, companies still have not felt a big impact yet. Therefore, considerable changes of performance measurement related with this process. Wed not observed however, 
changes are foreseen during upcoming several years, mostly in the company of electricity generation. Increasing competition between independent suppliers encourages forming a competitive strategy. Therefore, in this type of company the usage of PMS as the means of strategy implementation will be more relevant in comparison with companies of electricity distribution and transmission.

- Financial indicators were dominant in the performance measurement of all companies. However, the importance of non-financial indicators is constantly growing. As the most important non-financial indicators there were considered indirect costs, learning, perfection, quality and innovations. In some years the largest increase of the importance of indicators is foreseen in the evaluation of strategy implementation, customers' and other stakeholders' satisfaction, employees and intellectual capital.

Limitations and suggestions. The results of this research should be regarded as valid for the Lithuanian grand electricity companies alone. Considering the fact that the processes of electricity market liberalization due to short time had little impact on electricity companies, the authors suggest repeating this research after 3 or 5 years in order to investigate the changes of PMSs due market liberalization more properly.

\section{References}

Anderson, K., \& McAdam, R. (2004). A critique of benchmarking and performance measurement. Lead or lag. Benchmarking: an international Journal, 11(5), 465-483.

Bogicevic, J., \& Domanovic, V. (2009). Balanced Scorecard in Serbia: Management Innovation or Rhetoric Game. Perspectives of Innovations, Economics \& Business, 3, 83-85.

Bromley, M., Cuthbertson, R., Martinez, V., \& Kennerley, M. (2006). Insight from the Balanced Scorecard. Performance management at EDF Energy: ambition into action. Measuring Business Excellence, 10(3), 23-30.

Christauskas, C., \& Kazlauskiene, V. (2009). Moderniu veiklos vertinimo sistemu itaka imones valdymui globalizacijos laikotarpiu. Economics and Management, 14, 715-722.

Christauskas, C., \& Stunguriene, S. (2007). Research on difficulties of financial decision making under uncertainty conditions. Transformations in Business \& Economics, 6(2), 98-113.

Curado, C., \& Manica, J. (2010). Management Control Systems in Madeira Island Largest Firms: Evidence on the Balanced Scorecard Usage. Journal of Business Economics and Management, 11(4), 652-670.

Dagiliene, L., Kovaliov, R., Macerinskas, J., \& Simanaviciene, Z. (2006). The application of financial valuation methods in investment decisions. Vadyba / Management, 2(11), 28-33.

Galiniene, B., \& Marcinskas, A. (2007). Factors determining the quality of business valuation services in the transformation context. Transformations in Business \& Economics, 6(2), 38-50.

Gimzauskiene, E., \& Kloviene, L. (2008). The Role of Institutional Factors on Changes of Performance Measurement System. Economics and Management, 13, 22-29.

Gimzauskiene, E., \& Kloviene, L. (2010). Research of the Performance Measurement System: Environmental Perspective. Inzinerine Ekonomika-Engineering Economics, 21(2), 180-186.

Gimzauskiene, E., \& Valanciene, L. (2009). Performance Measurement System in the Context of Economics Changes. Economics and Management, 14, 31-41.

Ginevicius, R. (2009). Quantitative Evaluation of Unrelated Diversification of Enterprise Activities. Journal of Civil Engineering and Management 15(1), 105-111.

Ginevicius, R., \& Podvezko, V. (2009). Evaluating the changes in economic and social development of Lithuanian countries by multiple criteria methods. Technological and Economic Development of Economy, 15(3), 418-436.

Grodskis, D., Staskevicius J. A., \& Zemkauskas A. (2001). Organizacijos veiklos vertinimo sistema. Organizaciju vadyba: sisteminiai tyrimai, No. 20. Vytauto Didžiojo universitetas.

Haapasalo, H., Ingalsuo, K., \& Lekkeri T. (2006). Linking strategy into operation management. A survey of BSC implementation in Finish energy sector. Benchmarking: An international Journal. 13(6), 701-717.

Jasilioniene, R., \& Tamosiuniene, R. (2009). Evaluation of Customer Relationship System Efficiency: Applying of Total Cost of Ownership Approach. Journal of Business Economics and Management, 10(4), 343-347.

Kaplan, R. S., \& Norton, D. P. (1992). The balanced Scorecard - Measures that Drive Performance. Harvard Business Review. January - February.

Kazlauskiene, V., \& Christauskas, C. (2008). Business valuation model based on the analysis of business value drivers. Inzinerine Ekonomika-Engineering Economics(2), 23-31.

Kennerley, M., \& Neely, A. (2003). Measuring performance in a changing business environment. International Journal of Operation \& Production Management, 23(2), 213-229.

Kinderyte, L., Ciegis, R., \& Staniskis, J. K. (2010). Assessment of Enterprise Performance for Efficient Sustainability. Transformation in Business \& Economics. 9(3), 104-118.

Kloviene, L., \& Gimzauskiene, E. (2009) Performance Measurement System Changes According to Organization‘s External and Internal Environment. Economics and Management, 14, 70-77.

Lenz, B. (2008). Information models for assessment and management of development trends. Technological and Economic Development of Economy, 14(3), 444-447. 
Linas Jasiukevicius, Ceslovas Christauskas. The Application of Performance Measurement Systems...

Lynch, R. L., \& Cross, K. F. (1991). Measure up - the Essential Guide to Measuring Business Performance, Mandarin, London.

McAdam, R., \& Bailie, B. (2002). Business performance measures and alignment impact on strategy: The role of business improvement models. International Journal of Operation \& Production Management, 22(9), 972-996.

Muller, R., Steinert, M., \& Teufel, S. (2008) Successful diversification strategies of electricity companies: an explorative empirical study on the success of different diversification strategies of German electricity companies in the wake of the European market liberalization. Energy policy, 36, 398-412.

Neely, A. (2005). The evolution of performance measurement research. International Journal of Operation \& Production Management, 25(12), 1264-1277.

Neely, A., \& Bourne, M. (2002). Why measurement initiatives fail. Measuring Business Excellence, 4(4), 3-6.

Neely, A., Adams, C., \& Crowe, P. (2001). The performance prism in practice. Measuring Business Excellence, 5(2), 6-12.

Neely, A., Gregory, M., \& Platts, K. (2005) Performance measurement system design: A literature review and research agenda. International Journal of Operation \& Production Management, 25(12), 1228-1263.

Parker, Ch. (2000). Performance measurement. Work study. MCB University Press. 49(2), 63-66.

Pongatichat, P., \& Johnson, R. (2008). Exploring strategy-misaligned performance measurement. International Journal of Productivity and Performance Management, 57(5), 415-433.

Ponikvar, N., Tajnikar M., \& Pushnik K. (2009). Performance Ratios for Managerial Decision-Making in a Growing Firm. Journal of Business Economics and Management, 10(2), 109-120.

Rantanen, H., Kulmala, H., \& Lonnqvist A., et al. (2007). Performance measurement systems in the Finnish public sector. International Journal Of public Sector Management, 20(5), 415-433.

Roa, M. P. (2006). A performance measurement system using a profit-linked multi-factor measurement model. Industrial Management \& Data Systems, 106(3), 362-379.

Slizyte, A. (2009). Kompleksinio organizacijos veiklos vertinimo sistemos formavimas. Daktaro sidertacija.

Strumickas, M., \& Valanciene, L. (2009). Research of Management Accounting Changes in Lithuanian Business Organizations. Inzinerine Ekonomika-Engineering Economics(3), 27-32.

Tangen, S. (2005). Insights from practice. Analyzing the requirements of performance measurement systems. Measuring Business Excellence, 9(4), 46-54.

Tapinos, E., Dyson, R. G., \& Meadows, M. (2005). The impact of performance measurement in strategic planning. International Journal of Productivity and Performance Management, 54(5/6), 370-384.

Turskis, Z., Zavadskas, E. K., \& Peldschus, F. (2009). Multi-criteria Optimization System for Decision Making in Construction Design and Management. Inzinerine Ekonomika-Engineering Economics(1), 7-17.

Unahabhokha, C., Platts, K., \& Tan, K. H. (2007). Predictive performance measurement system. A fuzzy expert system approach. Benchmarking: an International Journal, 14(1), 77-91.

Valanciene, L., \& Gimzauskiene, E. (2007). Changing Role of Management Accounting: Lithuanian Experience Case studies. Inzinerine Ekonomika-Engineering Economics(5), 16-23.

Valanciene, L., \& Gimzauskiene, E. (2009). Dimensions of Performance Measurement System in Changes Research. Inzinerine Ekonomika-Engineering Economics(4), 41-48.

Walsh, P. R., \& Sanderson, S. T. (2008). Hybrid strategic thinking in deregulated retail energy markets. International Journal of Energy Sector Management, 2(2), 218-230.

Wouters, M., \& Sportel, M. (2005). The role of existing measures in developing and implementing performance measurement systems. International Journal of Operation \& Production Management. 25(11), 1062-1082.

Linas Jasiukevičius, Česlovas Christauskas

Organizacijos veiklos vertinimo sistemų taikymas Lietuvos elektros energetikos sektoriuje

Santrauka

Organizacijai būtina nuolat sekti ir analizuoti savo veiklą bei vertinti strateginių tikslų igyvendinimo rezultatus. Strateginių tikslų nustatymas yra strateginio valdymo priemonè, o poreikis nustatyti organizacijos strategijos igyvendinimo rezultatus vis auga. Todėl, kuriant organizacijos veiklos vertinimo sistemą (VVS), dažnai susiduriama su problema, kaip patikimai įvertinti įmonès veiklą ir strateginių tikslų pasiekimo rezultatus.

Paskutiniu metu rinka suformavo šiuolaikiškos VVS reikalavimus. Buvo sukurtos ir paplito įvairios pažangios VVS: subalansuotų rodiklių, veiklos prizmès, veiklos piramidès sistemos, Europos fondo kokybès vertinimo modelis ir kt. Šios sistemos skirtingu lygiu jungia daug įvairių tiek finansinių, tiek nefinansinių rodiklių: vidinès ir išorinès aplinkos vertinimą, kokybès, inovacijų, mokymosi, tobulëjimo, lankstumo, išteklių valdymą ir kt.

Organizacijos VVS pasirinkimas suprantamas kaip individualus kiekvienos organizacijos sistemos formavimas. Todèl netgi atskirų organizacijų. to paties pavadinimo VVS gali gerokai skirtis vertinimo rodikliais.

Tyrimo tikslas - ištirti organizacijos VVS taikymą ir jų pokyčius Lietuvos didžiosiose elektros gamybos, skirstymo ir perdavimo įmonėse. Tyrimo uždaviniai: 1) išnagrinèti organizacijos veiklos vertinimo ypatumus elektros energetikos įmonèse; 2) išanalizuoti igyvendinamos laisvos elektros rinkos poveikį didžiujų Lietuvos elektros gamybos, perdavimo ir skirstymo įmonių veiklos vertinimui.

Teorinių šaltinių analizė parodè, jog modernios VVS pasižymi tais pačiais veiklos vertinimo elementais ir ypatumais, tačiau, kaip sistemos, skiriasi, turi savų pranašumų ir trūkumų. Formuojant VVS, viena didžiausių problemų - pasirinkti tokį rodiklių rinkini, kuris aiškiai ir visapusiškai atspindètų organizacijos veiklą ir strateginių tikslų igyvendinimo rezultatus.

Dauguma tyrinėtoju modernią VVS pirmiausia sieja su organizacijos strategija kaip priemone organizacijos strateginėms funkcijoms reguliuoti. Šiu dienų rinkos tendencijos lemia, jog strateginių tikslų nustatymas ir jų igyvendinimas tapo paplitusiu organizacijos valdymo būdu. Todẻl konkurencinės strategijos ir organizacijos veiklos vertinimo sąsaja laikoma vienu iš esminių modernios VVS bruožų. Modernios sistemos pasižymi finansinių ir 
nefinansinių rodiklių balansu, strateginių tikslų su visomis organizacijos veiklomis susiejimu, pasekmiu ir priežasčių atspindèjimu, orientacija ị procesus ir tinkamumu juos naudoti visais organizacijos valdymo lygmenimis. Šie, palyginti su tradicinėmis sistemomis, ivvykę VVS pokyčiai rodo kad organizacijos veiklos aplinka daro tiesioginę itaką jų veiklos vertinimui ir naudojamoms VVS.

Lietuvos elektros energetikos sektoriuje vyksta struktūriniai pokyčiai. $2010 \mathrm{~m}$. prasidėjus elektros rinkos liberalizavimui atsiranda prielaidos didèti konkurencijai, taip pat poreikiui rengti konkurencinę strategiją ir vertinti jos igyvendinimo rezultatus. Šie pokyčiai elektros įmonems, ilgą laiką veikusioms valstybès reguliuojamame sektoriuje, sąlygoja problemas padidinti savo veiklos efektyvumą naudojant strategini pozicionavimą, nes dèl šių pasikeitimų reikia rasti ir atitinkamas priemones, leisiančias efektyviai nustatyti ir ivvertinti organizacijos veiklą bei strateginių tikslų igyvendinimo rezultatus.

Straipsnyje pateiktas empirinis tyrimas, atliktas $2010 \mathrm{~m}$. gegužès - birželio mėnesiais. Tyrimo metodologija pagrista prielaida, jog organizacijos veiklos aplinka tiesiogiai veikia organizacijos veikla, kuri atitinkamai sąlygoja organizacijos veiklos vertinimo pokyčius ir rengia atitinkamus reikalavimus organizacijos VVS. Tyrime dalyvavusių imonių atranka buvo įvykdyta remiantis ilgametès veiklos elektros energetikos rinkoje, dominuojančios padèties Lietuvos elektros energetikos rinkoje kriterijais. Duomenys surinkti, atliekant ekspertu interviu, ir apdoroti Kontent analizès metodu.

Tyrimas parode Lietuvos didžiujų elektros gamybos, skirstymo ir perdavimo įmonių veiklos vertinimo specifiką. Tyrimo duomenų analizè leido išsiaiškinti elektros rinkos liberalizavimo ịtaka šiu įmonių veiklai ir veiklos vertinimo rodiklių svarbai.

Remiantis teorinėmis prielaidomis, galima teigti: kad įmones veikla būtų sėkminga, labai svarbu efektyviai valdyti ir kontroliuoti jos veiklą. Kuo geresnè kontrolè, tuo geresnès galimybès reaguoti į ịvairius pokyčius. Siekdamos turèti gera veiklos kontrolę, imonès privalo turèti tinkamus rodiklius, leidžiančius efektyviai ir visapusiškai įvertinti jų veiklą. Todèl i̇monèms svarbu pasirinkti (suformuoti) tokią VVS, kuri leistu gauti visapusišką informaciją apie imoniu veiklą ir aplinką, kurioje jos veikia.

Mokslinès literatūros analizè parodè, kad organizacijos veiklos vertinimas ir reikalavimai VVS kito kartu su organizaciju veiklos aplinka ir vertybėmis. Šių dienų rinkos sąlygos išskyrẻ strategijos ir kitų nefinansinių rodiklių vertinimo svarbą. Todèl sąsajos tarp organizacijos veiklos ir konkurencinès strategijos bei finansinių ir nefinansinių rodiklių laikomos vienais svarbiausių modernių VVS bruožu.

Remiantis Lietuvos elektros energetikos sektoriaus pokyčiais, iškelta prielaida, kad didės konkurencija tarp imonių bei vartotoju pasitenkinimą nustatomų rodiklių vertinimo aktualumas. Tuo pačiu šios prielaidos leidžia teigti, kad didès ir modernių VVS taikymo aktualumas.

Atlikus Lietuvos didžiosiose elektros energetikos imonėse empirini tyrimą, galima teigti:

- Imonèse veiklos vertinimas daugiausiai taikomas kaip informacijos funkcija valdyti ir kontroliuoti i̇monių veiklą. Valstybinis įmonių veiklos reguliavimas lemia, jog pačiu imonių vaidmuo rengiant ir igyvendinant i̇monių veiklos strategiją yra palyginti mažas, daugiausia apsiriboja vidine imoniu veiklos aplinka.

- $\mathrm{ABC}$ sistema buvo daugiausiai paplitusi VVS tarp imonių. Taip pat visos įmonès taikẻ darbuotojų veiklos vertinimą. Didžiausi pokyčiai įmoniu veiklos vertinimo procese vyksta vertinant darbuotojų veiklą.

- Nors visų ¿̇monių VVS pasižymėjo strategijos igyvendinimo vertinimo ypatumais bei tinkamumu juo naudoti strateginiu valdymo lygmeniu, finansinis veiklos vertinimas dominavo vertinant visų imonių veiklą.

- VVS integracijos aspektu visų imonių VVS buvo labai panašios: apèmè visas veiklos sritis, orientuotos labiau į vidinės nei išorinès aplinkos vertinima, beveik visos standartizuotos ir dokumentuotos.

Apibendrinant elektros rinkos liberalizavimo poveikio įmonių veiklai ir veiklos vertinimo rodikliams tyrimo rezultatus, galima teigti kad:

- Laipsniškas elektros rinkos liberalizavimas iki šiol didelio poveikio neturejo, todèl nebuvo pastebėta jokiu reikšmingu vertinant imoniu veikla pasikeitimu siejamu su šiais rinkos pokyčiais. Tačiau pokyčiai numatomi po kelių metu, didžiausi - elektros gamybos įmonėse. Didèjanti konkurencija tarp nepriklausomu elektros tiekeju skatina formuoti konkurencinę strategija. Todèl, autoriu manymu, moderniu VVS naudojimas kaip priemonè strateginiams tikslams igyvendinti elektros gamybos i̇monèje turètų tapti aktualiausias, palyginti su kitomis i̇monèmis.

- Finansiniai rodikliai dominavo vertinant visų įmonių veiklą, tačiau ir nefinansinių rodiklių svarba nuolat auga. Elektros gamybos įmonės VVS, palyginti su kitų tipu imoniu VVS, išsiskiria tuo kad neapima veiklai darančių itaką bendradarbiavimo ir produktyvumo vertinimo rodiklių. Tačiau šioje i̇monėje numatoma kad bus itin aktualus strategijos vertinimo rodikliai. Skirstymo ir perdavimo įmonių VVS, palyginti su gamybos įmonės VVS, išsiskiria tuo, kad nèra konkurencijos vertinimo rodiklių.

Atlikto tyrimo teoriniai ir empiriniai duomenys apie VVS taikymą ir pokyčius Lietuvos didžiosiose elektros gamybos, skirstymo ir perdavimo ¿̇monèse sudaro prielaidas praplèsti mokslines žinias apie elektros rinkos liberalizavimą Lietuvoje.

Raktažodžiai: elektros energetikos sektorius, elektros rinkos liberalizavimas, veiklos vertinimo ypatumai, veiklos vertinimo sistema, strateginis valdymas.

The article has been reviewed.

Received in March, 2011; accepted in June, 2011. 